\title{
Flared Gas Emission Control from an Oil Production Platform
}

\author{
Dina Liyana Mohamed Roshidin Murad, ${ }^{1,2}$ Mohd Shamsul Mohd Nasir, ${ }^{3 *}$ \\ Li Chin Law, ${ }^{1,4}$ Iylia Idris ${ }^{1}$ and Mohd Roslee Othman ${ }^{1 * *}$ \\ ${ }^{1}$ School of Chemical Engineering, Universiti Sains Malaysia, \\ Engineering Campus, 14300 Nibong Tebal, Pulau Pinang, Malaysia
}

${ }^{2}$ Ibiden Electronics Malaysia Sdn. Bhd., 1049, Jalan Perindustrian Bukit Minyak 8, Kawasan Perindustrian Bukit Minyak, 14100 Simpang Ampat, Pulau Pinang, Malaysia

${ }^{3}$ Repsol Malaysia (Talisman Malaysia Limited), Menara Citibank, 165 Jalan Ampang, 50450 Kuala Lumpur, Malaysia

${ }^{4}$ JED Centre Sdn. Bhd., One Precinct, Jalan Mayang Pasir, Bandar Bayan Baru, 11950 Bayan Lepas, Pulau Pinang, Malaysia

Corresponding authors: msmnasir@repsol.com*; chroslee@usm.my**

Published online: 15 February 2019

To cite this article: Mohamed Roshidin Murad, D. L. et al. (2019). Flared gas emission control from an oil production platform. J. Phys. Sci., 30(Supp. 1), 125-147, https://doi.org/ 10.21315/jps2019.30.s1.8

To link to this article: https://doi.org/10.21315/jps2019.30.s1.8

\begin{abstract}
In Samarang oil platform of Repsol (Talisman) Malaysia Limited, there is a need to increase its current oil production that would result in an increase of the associated/excess gas from $21 \mathrm{mmscfd}$ to $31 \mathrm{mmscfd}$. The current low-pressure gas system on the platform is designed to accommodate up to 21 mmscfd of gas. The excess produced gas of 10 mmscfd, if not re-injected back into the reservoir, shall need to be flared on a daily basis in order to maximise the oil production rate. This gas flaring expends large amounts of energy and causes environmental degradation and potential health risk. There are four practical cases being considered in this unprecedented effort to control the flared gas and its resulting emissions from the industrially practical standpoint. Three cases use the existing compressor and varying compressor suction pressure between 5 barg and 6 barg with total compressors power is limited up to $2280 \mathrm{~kW}$. The flared gas emission for these cases ranges from $7 \mathrm{mmscfd}$ to $1 \mathrm{mmscfd}$, which is lower than the expected flowrate of $10 \mathrm{mmscfd}$. In the case where a new compressor is installed, a zero flared rate is achieved.
\end{abstract}

Keywords: Sustainability, environment, gas flare, hydrocarbon, natural gas 


\section{INTRODUCTION}

Natural gas consumption is rapidly expanding and currently is the third largest global energy source. Its utilisation is expected to rise substantially in the coming decades due to its availability, versatility and sustainability. Natural gas is poised to bridge the gap between the carbon-intensive and zero carbon energy gradually into a more sustainable, carbon neutral and greener energy system. ${ }^{1}$ Despite the potential of natural gas as clean energy, there is a concern over venting large volumes of the gas into the atmosphere from the gas processing facilities through flaring when the gas is produced in an unexpectedly larger volume than the gas infrastructures can accommodate. This excess gas (termed as waste or associated gas) produces large amount of greenhouse gases, impurities and toxic particles when it is flared, making it environmentally unfavourable and hazardous.

About 115 billion cubic metres ( $\mathrm{bcm}$ ) of the associated gas is reportedly vented out into the atmosphere every year. ${ }^{2}$ Estimates from satellite data indicated that more than $139 \mathrm{bcm}$ of the gas (equivalent to $4.6 \%$ of the world natural gas consumption) is flared annually. ${ }^{3}$ It has been projected that annual flaring would increase by $60 \%$ from 1999 to 2020 if there is no effort to reduce the current flared activity. ${ }^{4}$ The flared activity reportedly produces 281 million tons of $\mathrm{CO}_{2}$ emissions annually, which is a few million tons higher than the forecasted $\mathrm{CO}_{2}$ emissions from Malaysia and Indonesia coal fired power plants by 2020., ${ }^{5,6}$ This flared activity would adversely offset the expected environmental relieve from the in-situ mineralisation of carbon dioxide or other noble approaches in preserving the environment. ${ }^{7}$ In addition, the impurities and the toxic particles and gases such as $\mathrm{H}_{2} \mathrm{~S}$ released into the atmosphere, with or without flaring, would pose a significant health hazard to living beings. ${ }^{8}$

There are alternatives for dealing with the excess gas that would otherwise be directed to the flare. One of them is by way of gas-to-liquid (GTL) technology to create wealth from waste. This technology transforms the associated gas into liquids for fuels and petrochemical feedstock that otherwise goes to waste and is flared to the atmosphere. This technology plays an important role in adding value to the gas initially considered as waste into liquid fuel and valuable petrochemicals. ${ }^{9}$ The other method that would add value to the waste gas include methane enrichment/separation from $\mathrm{CO}_{2}$ using physical adsorption such as pressure swing adsorption, mineralisation and membranes, collection and compression of gas into pipelines for processing and sale, generation of electricity or co-generation of heat and electricity using conventional gas turbines, micro turbines, or other gasfired engines, and compression-reinjection of the gas back into an underground reservoir. ${ }^{5,7,10-19}$ 
In Samarang oil platform (KNDP-A platform) of Talisman Malaysia Limited (TML), there is a need to increase its current oil production that will result in increase of the associated gas from $21 \mathrm{mmscfd}$ to $31 \mathrm{mmscfd}$. The current low pressure (LP) gas system on the platform is designed to accommodate up to $21 \mathrm{mmscfd}$ of gas. The excess produced gas of $10 \mathrm{mmscfd}$, if not re-injected back into the reservoir, will need to be flared on a daily basis in order to maximise the oil production rate. The LP gas system in the KNDP-A oil platform is essentially composed of LP separator, LP compressor, gas scrubber and its associated control system. Here, we report results of our attempt to minimise the flared rate and maximise the oil production by either improving the control strategy around the present LP gas system or implementing modification on the equipment to accommodate the higher produced gas rate.

\section{EXPERIMENTAL}

The KNDP-A oil field processing scheme is designed with three stages of gasliquid separation for crude partial stabilisation such as shown in Figure 1. Produced fluids from wells are combined and routed to the appropriate two-phase separator according to flow tubing head pressure (FTHP) of the wells. High pressure well fluid (oil, water and gas) with FTHP more than 40 barg is routed to highly high pressure (HHP) separator, V-1010, operating at 36 barg. Well fluid with FTHP between 24 barg and 36 barg is combined with liquid exiting the HHP separator and routed to high pressure (HP) separator, V-1020 operating at $23 \mathrm{barg}$.

The low pressure well fluid is combined with liquid exiting HP separator and directly routed to low pressure (LP) separator, V-1030, operating within the range of 5-6 barg such as shown in Figure 1. The partially stabilised liquid (oil and produced water) is exported to the receiving facilities using crude oil transfer pumps. From the oil field, the crude oil is eventually sent to a terminal for storage before being lifted by the oil tanker.

The low-pressure gas evolving in LP separator is separated and compressed by a two stages LP compressor, K-2430, to 23 barg pressure. The gas is routed to the flare system for direct flaring if the gas flowrate exceeds the compressor capacity of $21 \mathrm{mmscfd}$. The gas from LP compressor discharge combines with gas from HHP separator and HP separator before entering a vertical gas export scrubber, $\mathrm{V}-2610$, to remove any condensed liquid from the gas stream. The gas exiting the scrubber is routed to fuel gas skid for further treatment before being used as fuel in order to power up gas turbine generator, purge gas for flare system and compressor seal gas. On the other hand, the gas exiting from the scrubber is compressed further by HP compressor (K-2500) to approximately 90 barg, before being used as lift gas to enhance oil production on low pressure and high water cut wells. 


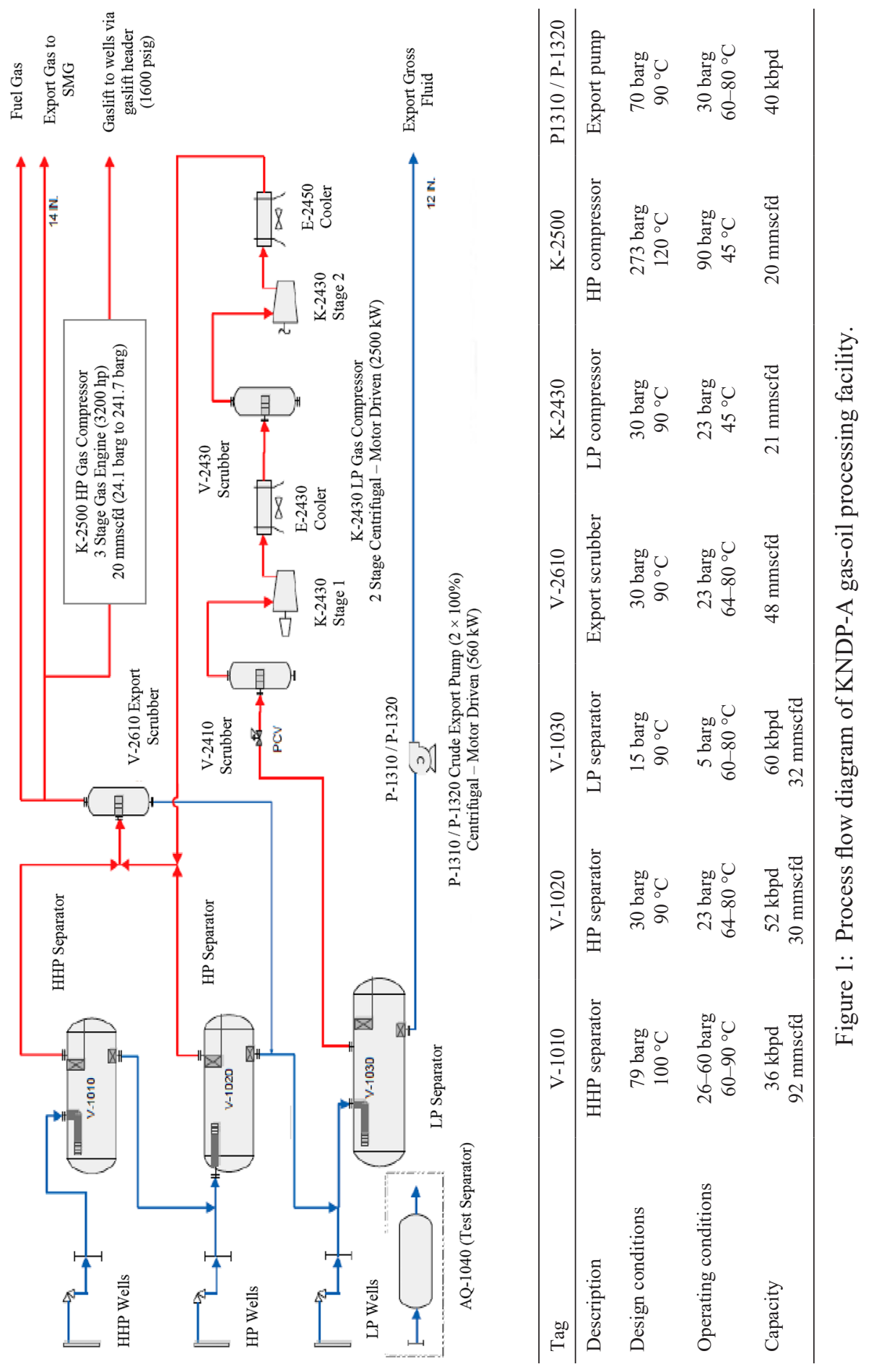




\subsection{Defining Design Case}

The current LP gas system on the KNDP-A platform is designed to accommodate up to $21 \mathrm{mmscfd}$ of the associated gas. There is a need to increase the capacity to $31 \mathrm{mmscfd}$ as a result of the increase in oil production. The excess produced gas of $10 \mathrm{mmscfd}$ will need to be flared on a daily basis in order to maximise the oil production rate. There are four practical cases that can be opted to minimise the gas flared rate from the LP gas system.

In Case 1, the existing compressor (K-2430) pressure inlet at 5 barg and 6 barg are considered in the study, respectively. The feed gas flowrate to LP separator is increased from $21 \mathrm{mmscfd}$ to $31 \mathrm{mmscfd}$ at $69.46^{\circ} \mathrm{C}$ (due to the higher temperature and volume changes in the gas) in order to minimise the gas being diverted to the flare, while maintaining the discharge pressure at second stage compressor to $23 \mathrm{barg}$. The total power for both first and second stages of the compressor is kept under $2280 \mathrm{~kW}$ and the existing compressor characteristic is used. The data of the performance curves, including the volume flowrate, efficiency and head for both compressors are shown in Table 1, obtainable from the HYSYS solver.

Table 1: Design specification of first and second stage compressors for Case 1.

\begin{tabular}{cccc}
\hline & Head $\times 10^{3}\left(\mathrm{~m}^{2} \mathrm{~s}^{-2}\right)$ & Volume flow $\times 10^{3}\left(\mathrm{~m}^{3} \mathrm{~h}^{-1}\right)$ & Efficiency $(\%)$ \\
\hline & 153.05 & 4.00 & 74.00 \\
& 146.75 & 5.00 & 76.00 \\
1st stage compressor & 137.85 & 6.00 & 77.78 \\
& 132.27 & 6.50 & 77.90 \\
& 124.44 & 7.00 & 77.78 \\
& 113.36 & 7.50 & 75.00 \\
\hline \multirow{5}{*}{ 2nd stage Compressor } & 121.15 & 1.50 & 64.16 \\
& 117.82 & 1.75 & 65.83 \\
& 113.37 & 2.00 & 66.94 \\
& 102.26 & 2.50 & 67.78 \\
& 93.36 & 2.75 & 66.67 \\
\hline
\end{tabular}

In Case 2, zero flaring is attempted by routing the maximum of $31 \mathrm{mmscfd}$ of the feed gas flowrate to the LP gas system using a new compressor with higher capacity. The discharge pressure at the second stage of the compressor is maintained at $23 \mathrm{barg}$. Since a new and larger capacity compressor is needed, the new compressor characteristic such as performance curve, electrical power consumption and gear ratio are used. Here, there is no limitation on the total power of the compressor. 
In Case 3, a minor modification on the existing compressors (K-2430) is attempted and new data performance curve of each compressor is used. These data are shown in Table 2. In addition, the compressor total electrical power is maintained at or below $2280 \mathrm{~kW}$ like in Case 1.

Table 2: Design specification of first and second stage compressors for Case 3.

\begin{tabular}{lccc}
\hline & Head $\times 10^{3}\left(\mathrm{~m}^{2} \mathrm{~s}^{-2}\right)$ & Volume flow $\times 10^{3}\left(\mathrm{~m}^{3} \mathrm{~h}^{-1}\right)$ & Efficiency $(\%)$ \\
\hline \multirow{2}{*}{ 1st stage compressor } & 146.00 & 3.60 & 75.50 \\
& 140.00 & 4.40 & 78.00 \\
& 132.00 & 5.40 & 80.00 \\
& 124.00 & 6.00 & 80.00 \\
& 108.00 & 6.80 & 78.00 \\
\multirow{2}{*}{ 2nd stage Compressor } & 102.00 & 7.10 & 76.30 \\
& 92.00 & 2.05 & 71.50 \\
& 88.00 & 2.50 & 73.50 \\
& 84.00 & 2.90 & 74.50 \\
& 80.00 & 3.10 & 74.90 \\
& 76.00 & 3.40 & 74.00 \\
& 58.00 & 4.05 & 67.00 \\
\hline
\end{tabular}

In Case 4, the flared rate is minimised by reducing the discharge pressure at the second stage compressor (K-2430) from 23 barg to 22 barg. The feed gas flowrate to LP separator is maintained within the range of $21 \mathrm{mmscfd}$ to $31 \mathrm{mmscfd}$ with total compressor power of less than $2280 \mathrm{~kW}$.

The first step of the work is to setup the HYSYS model that represents the practical design cases discussed earlier. The layout is depicted in Figure 2. Peng-Robinson thermodynamic fluid package, which is recommended for offshore processing facilities, is applied during the simulation since it solves any single, two-phase or three-phase system with high degree of efficiency and reliability. ${ }^{20}$ Lee Kesler enthalpy is selected in a combined property package employing the appropriate equation of state for vapour-liquid equilibrium calculations as well as Lee Kesler equation for the calculation of enthalpies and entropies. ${ }^{21}$

The HYSYS model is used to determine the amount of gas flowrate diverted to the flare. During the process simulation, certain variables cannot be changed or specified directly because of the issue of non-convergence. Instead, the variables are changed accordingly to match the desired process specification. Therefore, the adjust block is used for this purpose to vary the value of one stream variable to meet the required value in another stream or operation. LP separator is a two- 


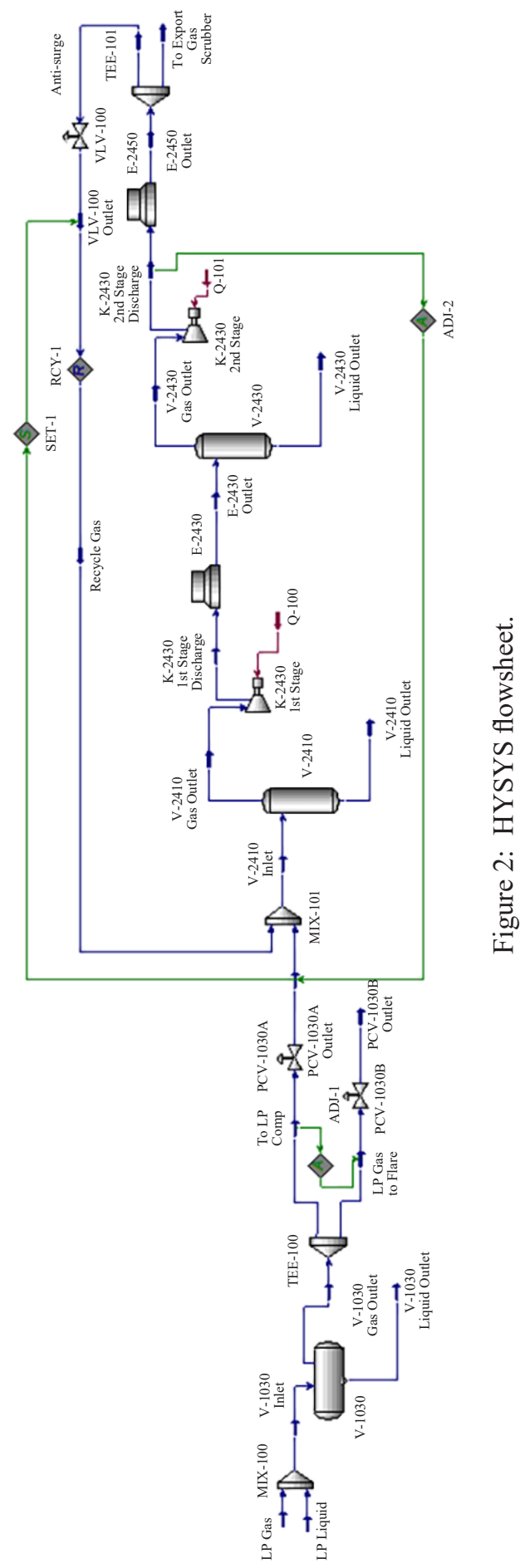


phase separator type. It is considered that the two streams which are gas and liquid streams flowing to the mixer with the same temperature and pressure. The compressor work is specified in all practical cases with different design conditions while, the efficiency is calculated by the solver. The compressor used is in a centrifugal operating mode. ${ }^{22}$

\section{RESULTS AND DISCUSSION}

\subsection{Case 1: Existing Compressor (K-2430)}

Figure 3 shows the relationship between LP gas compressor flowrate and flare emission rate at two different feed pressures. Gas flared rate decreases when the feed gas routed to the LP compressor is increased. For this process, the intent is to minimise the gas flared rate in order to produce high compressor's capacity because the existing capacity of the compressor is $21 \mathrm{mmscfd}$. The original suction pressure at first stage compressor inlet is 3.45 barg. ${ }^{23}$ If the suction pressure is increased while maintaining the discharge pressure at the second stage compressor at $23 \mathrm{barg}$, the compression ratio will decrease. ${ }^{24}$ The decrease in compression ratio will give raise to higher temperature and volume changes in the gas, resulting in an increase in the compressor capacity. ${ }^{25}$

However, since the maximum motor power is limited to $2280 \mathrm{~kW}$, the maximum achievable compressor's capacity is $24 \mathrm{mmscfd}$ at 4.2 barg suction pressure at first stage compressor. Increasing the flowrate to higher than $24 \mathrm{mmscfd}$ by increasing the first stage compressor inlet pressure over 4.2 barg exceeds the current motor power rating. Therefore, varying the LP separator pressure does not benefit the system as far as compressor capacity is concerned. However, it does help to provide higher system operating margin and hence stabilise the system. ${ }^{26}$ Besides, the gas flared rate can be reduced from $10 \mathrm{mmscfd}$ to $7 \mathrm{mmscfd}$ using the existing compressor system.

Figure 4 represents the total power of compressor with the flowrate of LP compressor at 5 barg and 6 barg, respectively. For Case 1, the maximum compressor powers that work for 5 barg and 6 barg are $2239 \mathrm{~kW}$ and $2236 \mathrm{~kW}$, respectively. The existing motor capacity is limited up to $2280 \mathrm{~kW}$ indicated by the dashed line in the figure. Therefore, the maximum feed that should be delivered is $24 \mathrm{mmscfd}$ in order to achieve reduction in flare emission from $10 \mathrm{mmscfd}$ to $7 \mathrm{mmscfd}$ (refer to Figure 3). 


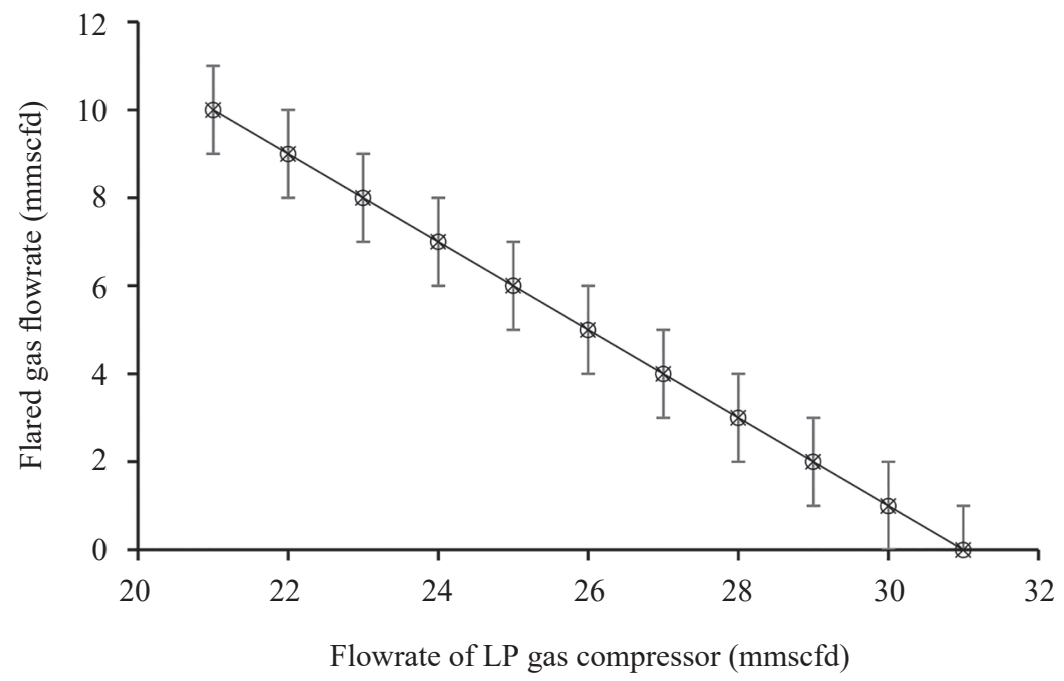

Figure 3: Flared gas flowrate against flowrate of LP gas compressor (Case 1).

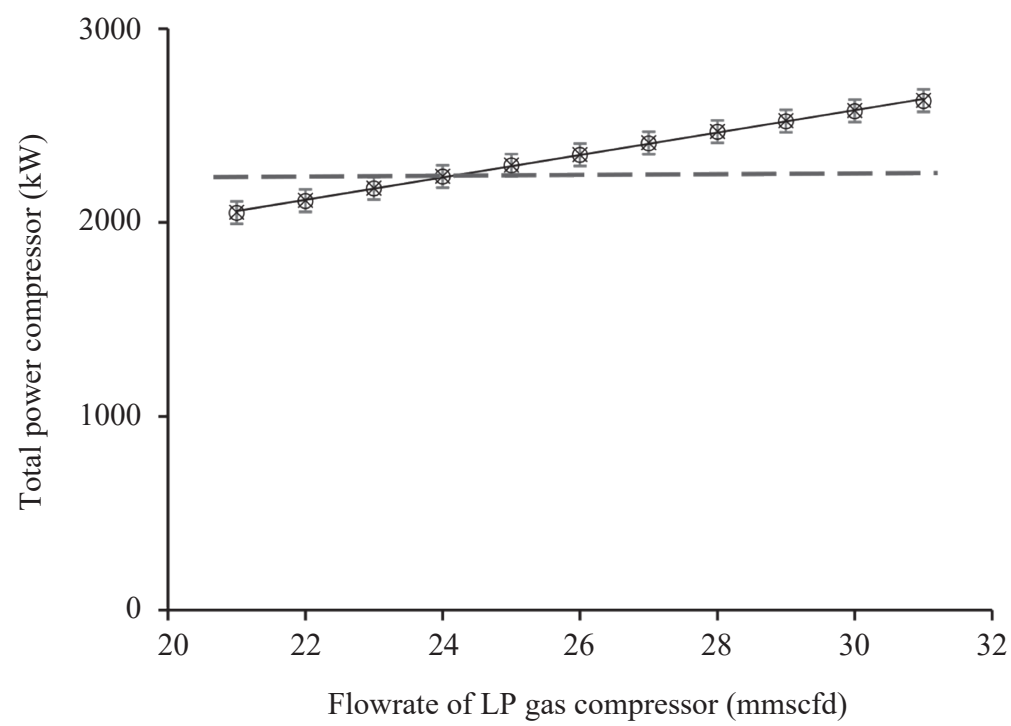

Figure 4: Total power compressor against flowrate of LP gas compressor (Case 1).

Figure 5 shows that the flowrate of LP gas compressor increases as the suction pressure at the first stage compressor is increased. In response to this change, the pipe and valve re-sizing must be calculated to check whether the other components in the LP compression system have the capacity to allow the flow of $24 \mathrm{mmscfd}$ feed gas calculated earlier. The pressure drop for 5 barg at PCV-1030A is 0.8 bar 
while the pressure drop for 6 barg is 1.8 bar. The calculated mass flowrate that allows for $24 \mathrm{mmscfd}$ is $39,015 \mathrm{~kg} \mathrm{~h}^{-1}$. Therefore, the control valve opening for linear valve is $77 \%$. Besides, the calculated flowrate for 6 barg to allow $24 \mathrm{mmscfd}$ to the compressor gas system is $38,685 \mathrm{~kg} \mathrm{~h}^{-1}$, and the control valve opening is $51 \%$. Therefore, both feed pressures are found to be the best option to minimise the gas flared flowrate to $7 \mathrm{mmscfd}$ since the good opening is in the range of $15 \%$ to $85 \%$ even though the gas flared rate is higher than maximum daily allowable flared limit on platform which is $6 \mathrm{mmscfd}$. Here, a linear characteristic recommended in the selection of the proper flow characteristic is applied. ${ }^{27}$

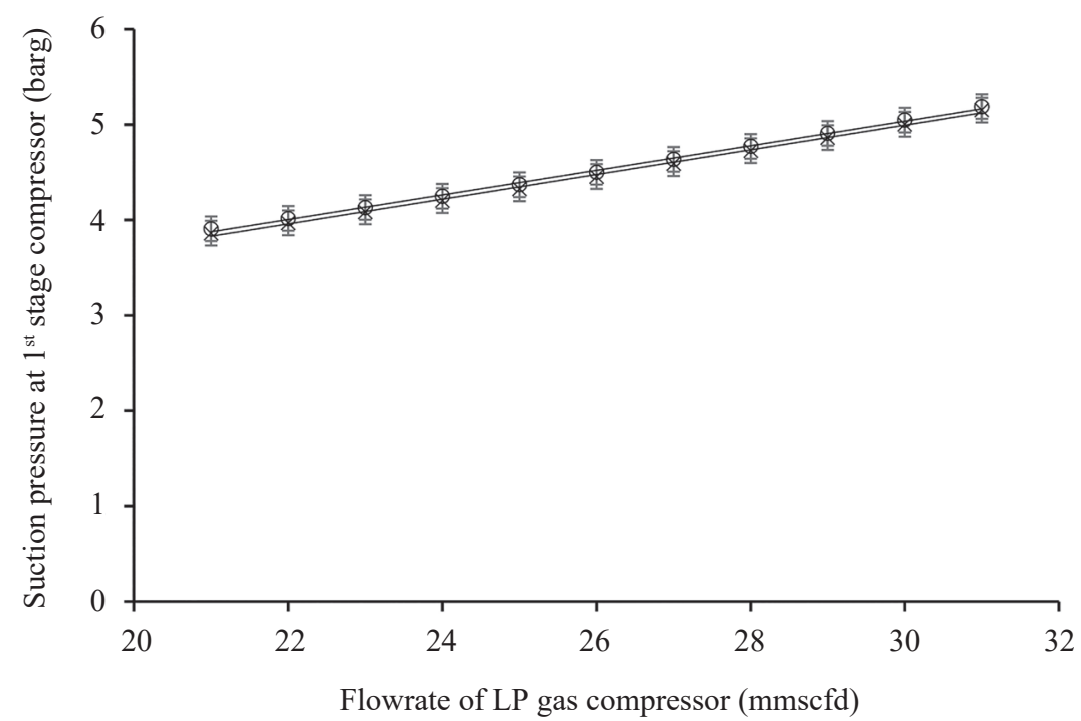

Figure 5: Suction pressure at first stage compressor against flowrate of LP gas compressor (Case 1).

\subsection{Case 2: New Higher Capacity LP Compressor}

Case 2 is designed to study the possibility of achieving zero flare emission from the LP gas system. A new LP compressor is used and there should be no limitation on the power of the compressor in Case 2 (in contrast to Case 1, where the power is limited to $2280 \mathrm{~kW}$ ). The power requirement and other specifications of this new compressor are calculated by the program. Results of the simulation and the process setting after the new compressor is integrated are shown in Table 3 and 4, respectively. 
Table 3: The characteristics of the first stage compressor.

\begin{tabular}{lc}
\hline First stage compressor & \\
\hline Compressor speed (rpm) & 11560 \\
Motor rated power (kW) & 3056 \\
Molar flow (mmscfd) & 31.06 \\
Pressure drop (kPa) & 680 \\
Power consumed (kW) & 1402 \\
Suction pressure of first stage compressor (barg) & 4.0 \\
Discharge Pressure of First Stage Compressor (barg) & 10.80 \\
\hline Composition of gas & \\
\hline Carbon dioxide & 0.0049 \\
Nitrogen & 0.0000 \\
Methane & 0.7885 \\
Ethane & 0.0578 \\
Propane & 0.0422 \\
i-Butane & 0.0086 \\
n-Butane & 0.0150 \\
i-Pentane & 0.0067 \\
n-Pentane & 0.0062 \\
$\mathrm{H}_{2} \mathrm{O}$ & 0.0502 \\
Other elements & 0.0199 \\
\hline
\end{tabular}

Table 4: The characteristics of the second stage compressor.

\begin{tabular}{lc}
\hline Second stage compressor & \\
\hline Compressor speed (rpm) & 11560 \\
Motor rated power (kW) & 3056 \\
Molar flow (mmscfd) & 30.0 \\
Pressure drop (kPa) & 1360 \\
Power consumed (kW) & 1375 \\
Suction pressure of second stage compressor (barg) & 9.4 \\
Discharge pressure of second stage compressor (barg) & 23.0 \\
\hline Composition of gas & \\
\hline Carbon dioxide & 0.0051 \\
Nitrogen & 0.0000 \\
Methane & 0.8162 \\
Ethane & 0.0598 \\
Propane & 0.0436 \\
i-Butane & 0.0089 \\
n-Butane & 0.0155 \\
i-Pentane & 0.0069 \\
n-Pentane & 0.0064 \\
$\mathrm{H}_{2} \mathrm{O}$ & 0.0197 \\
Other elements & 0.0179 \\
\hline
\end{tabular}


From the graph plotted in Figure 6, the gas flared rate decreases when the feed gas flowing into the new LP gas compressor is increased. For this case, the maximum gas flowrate of $31 \mathrm{mmscfd}$ is allowed into the LP compressor, leading to zero gas flaring. Both feed pressures have the same compressor's capacity and flared rate.

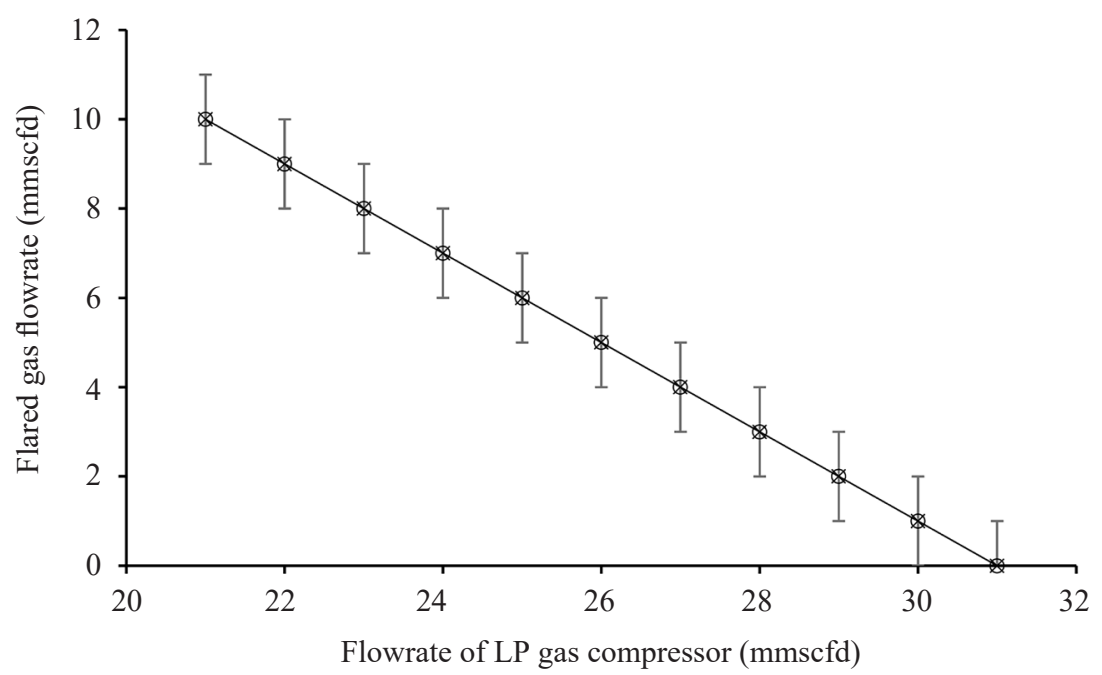

Figure 6: Flared gas flowrate against flowrate of LP gas compressor (Case 2).

The data of the compressor curves express the pressure ratio and the compressor efficiency in terms of rotational speed and also reduced mass flow. HYSYS allows setting of the characteristic curves for a new compressor in terms of volumetric flow, compressor head and efficiency for a given speed of $11560 \mathrm{rpm} .{ }^{22}$ Therefore, the new curves are not the same as those in Case 1. HYSYS uses these characteristic curves in order to calculate the stream outlet conditions and the compressor variables for a certain LP gas flowrate.

From Figure 7, it is shown that the power requirement is $2778 \mathrm{~kW}$ and $2791 \mathrm{~kW}$ for 5 barg and 6 barg, respectively, higher than those discussed in Case 1. However, in this case zero flare emission is achieved. In Case 1, the existing design motor power is $2500 \mathrm{~kW} .{ }^{23}$ It is about $8.8 \%$ of the difference between the design motor power and the applied power from the existing motor. Applying this contingency, the new design motor power which is $3100 \mathrm{~kW}$ is needed in order to achieve zero flare emission.

The suction pressure at first stage compressor is calculated at 4 barg for all flowrate of LP gas compressor. The velocity for the gas routed to the gas compression system with 5 barg feed pressure is $4.65 \mathrm{~m} \mathrm{~s}^{-1}$ and the pressure discharge loss is 
4.021 bar. Meanwhile, the velocity of 6 barg feed pressure for the gas travelling through the pipe is $4.69 \mathrm{~m} \mathrm{~s}^{-1}$ and the pressure loss is the same as the 5 barg feed pressure. Based on the calculation for control valve sizing, the pressure drop for feed pressure 5 barg and 6 barg are 1.0 bar and 2.0 bars, respectively such as listed in Table 5. Therefore, the mass flowrate for 6 barg is lower than 5 barg, which is $49,980 \mathrm{~kg} \mathrm{~h}^{-1}$ due to the higher pressure drop. ${ }^{28}$

Besides, the opening valve for feed pressure at 6 barg is $63 \%$, which is considered as good opening valve operating characteristic whereas the opening valve for feed pressure at 5 barg is $90 \%$, which is not in the range of the good opening valve $(15 \%-85 \%)$. Therefore, the latter is not a good option due to safety consideration.

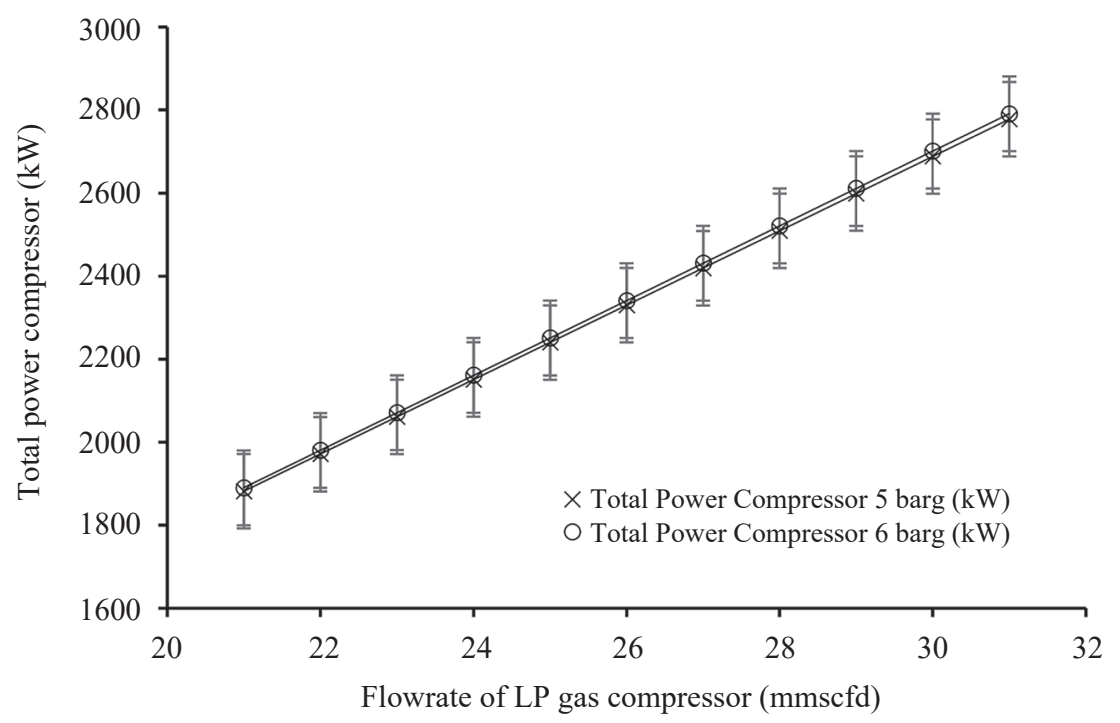

Figure 7: Total power compressor against flowrate of LP gas compressor (Case 2).

Table 5: Characteristics of PCV-1030A (Case 2).

\begin{tabular}{lcc}
\hline Characteristics & $\begin{array}{c}\text { Feed pressure } \\
(5 \text { barg })\end{array}$ & $\begin{array}{c}\text { Feed pressure } \\
(6 \text { barg })\end{array}$ \\
\hline Pressure drop (bar) & 1.0 & 2.0 \\
Mass flowrate $\left(\mathrm{kg} \mathrm{h}^{-1}\right)$ & 50,385 & 49,980 \\
Fluid (liquid and vapour) density $\left(\mathrm{kg} \mathrm{m}^{-3}\right)$ & 4.7 & 5.4 \\
Calculated valve sizing coefficient, $\mathrm{C}_{\mathrm{v}}$ & 937.64 & 657.42 \\
Flow characteristic - opening $(\%)$ & 90.2 & 63.2 \\
Opening valve operating characteristic - Linear $(\%)$ & 90 & 63 \\
\hline
\end{tabular}




\subsection{Case 3: Modified Existing LP Compressor (K-2430)}

Case 3 is a repeat of Case 1 but the existing compressor is modified and there is a new performance curve imposed on the compressor during operation. The modified compressor setting is given in Table 6 . The results from this setting such as flowrate of LP gas compressor, gas flared rate, total power of compressors and suction pressure at first stage of the compressor are shown in Table 6 and Table 7. Currently, LP separator operates at operating feed pressure inlet, $\mathrm{P}_{\mathrm{i}}$ of up to 6 barg. From Figure 8, it is shown that the compressor is capable of taking up to $30 \mathrm{mmscfd}$ of feed gas and routing the remaining $1 \mathrm{mmscfd}$ to the flare due to the power requirement of $2280 \mathrm{~kW}$.

Table 6: Results of Case 3 for 5 barg.

\begin{tabular}{cccc}
\hline $\begin{array}{c}\text { LP gas compressor } \\
\text { flowrate (mmscfd) }\end{array}$ & $\begin{array}{c}\text { Flared gas flowrate } \\
(\mathrm{mmscfd})\end{array}$ & $\begin{array}{c}\text { Total power of } \\
\text { compressor }(\mathrm{kW})\end{array}$ & $\begin{array}{c}\text { Suction pressure at 1st } \\
\text { stage compressor (barg) }\end{array}$ \\
\hline 21 & 10.0 & 1801 & 4.439 \\
22 & 9.0 & 1859 & 4.534 \\
23 & 8.0 & 1914 & 4.629 \\
24 & 7.0 & 1968 & 4.726 \\
25 & 6.0 & 2019 & 4.829 \\
26 & 5.0 & 2070 & 4.943 \\
27 & 4.0 & 2121 & 5.059 \\
28 & 3.0 & 2170 & 5.176 \\
29 & 2.0 & 2216 & 5.298 \\
30 & 1.0 & 2257 & 5.430 \\
31 & 0.0 & 2296 & 5.563 \\
\hline
\end{tabular}

Table 7: Results of Case 3 for 6 barg.

\begin{tabular}{cccc}
\hline $\begin{array}{c}\text { LP compressor } \\
\text { flowrate (mmscfd) }\end{array}$ & $\begin{array}{c}\text { Flared fas flowrate } \\
(\text { mmscfd) }\end{array}$ & $\begin{array}{c}\text { Total power of } \\
\text { compressor }(\mathrm{kW})\end{array}$ & $\begin{array}{c}\text { Suction pressure at 1st } \\
\text { stage compressor (barg) }\end{array}$ \\
\hline 21 & 10.0 & 1798 & 4.486 \\
22 & 9.0 & 1855 & 4.578 \\
23 & 8.0 & 1911 & 4.673 \\
24 & 7.0 & 1964 & 4.769 \\
25 & 6.0 & 2016 & 4.871 \\
26 & 5.0 & 2067 & 4.981 \\
27 & 4.0 & 2118 & 5.095 \\
28 & 3.0 & 2167 & 5.209 \\
29 & 2.0 & 2213 & 5.329 \\
30 & 1.0 & 2255 & 5.457 \\
31 & 0.0 & 2300 & 5.598 \\
\hline
\end{tabular}




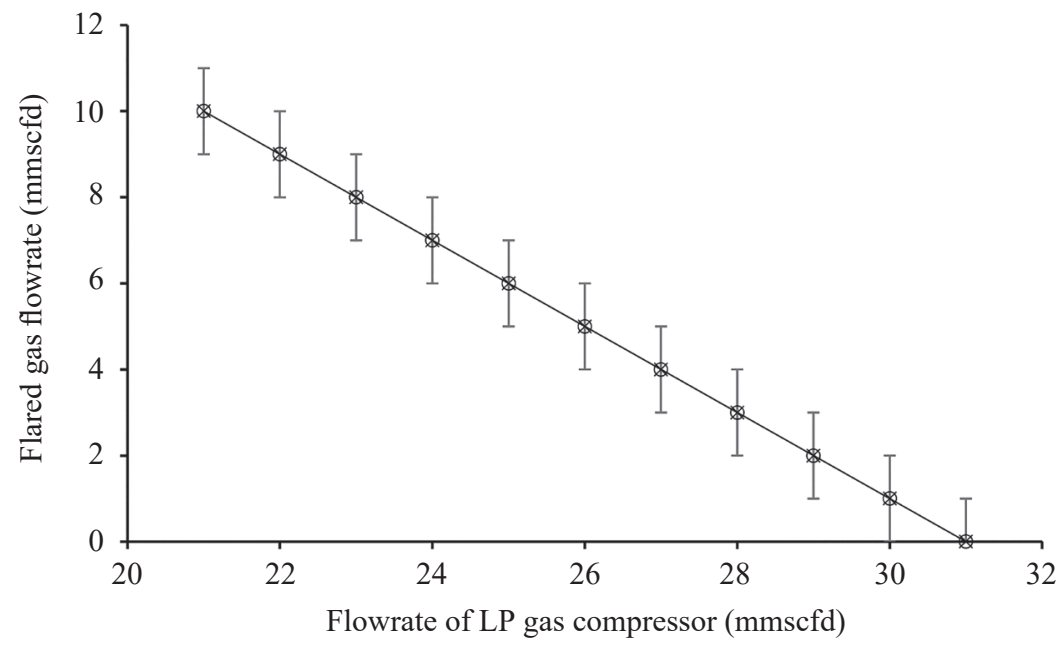

Figure 8: Flared gas flowrate against flowrate of LP gas compressor (Case 3).

Figure 9 shows the relationship between compressor power and the LP gas compressor flowrate for Case 3 . The results show that the maximum gas flowrate of $30 \mathrm{mmscfd}$ of feed gas and the remaining $1 \mathrm{mmscfd}$ can be delivered to LP gas system and the flare, respectively. Using the power compressor at $31 \mathrm{mmscfd}$ exceeds the $2280 \mathrm{~kW}$ limit as described earlier.

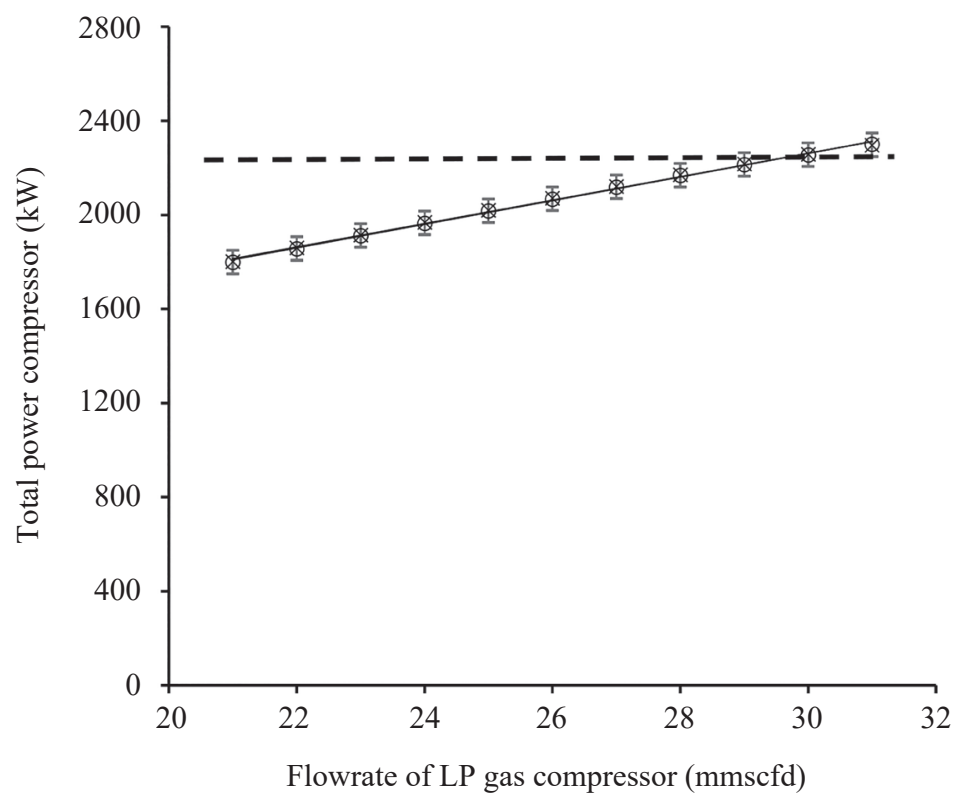

Figure 9: Total power compressor against flowrate of LP gas compressor (Case 3). 
The suction pressure at first stage of the compressor as a function of flowrate of LP gas compressor is given in Figure 10. The excess gas is discharged to the LP flare header through PCV-1030B while the remaining gas is routed to the LP compressor through PCV-1030A. The suction pressure increases linearly with the flowrate of LP gas compressor which is $5.457 \mathrm{barg}$ for the flowrate of $30 \mathrm{mmscfd}$ due to the $9 \%$ pressure losses from the separator pressure inlet of 6 barg. The separator pressure inlet of 5 barg only allows maximum flowrate of 26 mmscfd due to the suction pressure that is higher than the pressure inlet for the higher gas flowrate. Continuing with such flowrate causes the control valve to loop endlessly. The capacity control of compressor is done through PCV-1030A to prevent the compressor from ceasing upon high in-line pressure. ${ }^{29}$

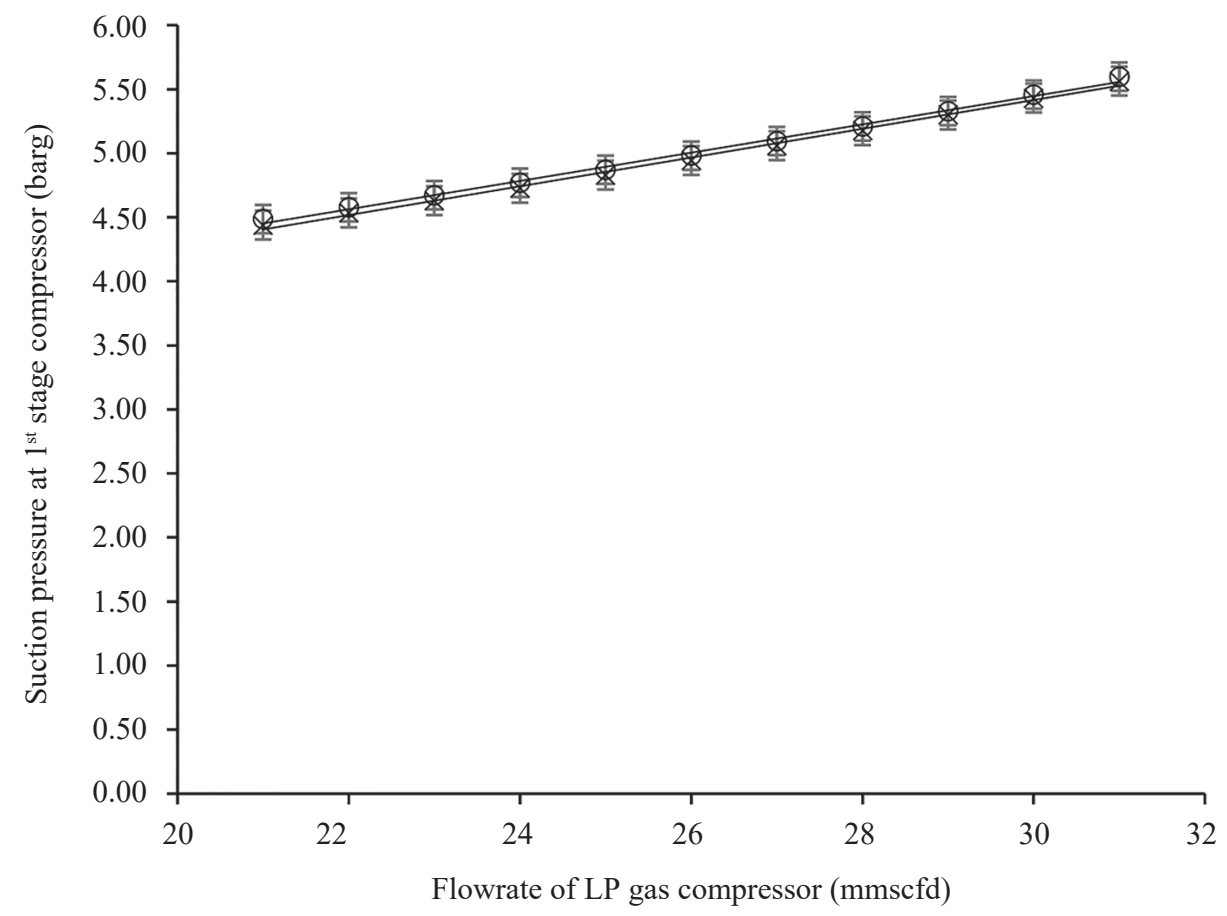

Figure 10: Suction pressure at first stage of compressor against flowrate of LP gas compressor (Case 3).

By changing the compressor specifications, valve re-sizing on PCV-1030A and calculation of suction pressure losses are needed. The gas velocity inside the pipeline is $20.23 \mathrm{~m} \mathrm{~s}^{-1}$. The suction pressure loss is 0.608 bar which is quite similar to the pressure loss in Case 1. Besides, the use of different performance curve also affects these parameters. From the calculation of control valve sizing, the pressure 
drop for feed pressure of 5 barg and 6 barg is 0.1 bar and 0.5 bar, respectively (Table 8). The mass flowrate for feed pressure of 5 barg and 6 barg is $42,270 \mathrm{~kg} \mathrm{~h}^{-1}$ and $48,360 \mathrm{~kg} \mathrm{~h}^{-1}$, respectively. The opening valve for this case, however, is more than $100 \%$. This is not a good opening because the opening valve higher than $85 \%$ is considered unrealistic. ${ }^{30}$ It is an under sized valve which is fairly uncommon.

Table 8: Characteristics of PCV-1030A (Case 3).

\begin{tabular}{lcc}
\hline Characteristics & $\begin{array}{c}\text { Feed pressure } \\
(5 \mathrm{barg})\end{array}$ & $\begin{array}{c}\text { Feed pressure } \\
(6 \text { barg })\end{array}$ \\
\hline Pressure drop (bar) & 0.1 & 0.5 \\
Mass flowrate $\left(\mathrm{kg} \mathrm{h}^{-1}\right)$ & 42,270 & 48,360 \\
Fluid (liquid and vapour) density $\left(\mathrm{kg} \mathrm{m}^{-3}\right)$ & 4.7 & 5.4 \\
Calculated valve sizing coefficient, $\mathrm{C}_{\mathrm{v}}$ & 3014.24 & 1078.29 \\
Flow characteristic - Opening $(\%)$ & $>100$ & $>100$ \\
Opening valve operating characteristic - Linear $(\%)$ & $>100$ & $>100$ \\
\hline
\end{tabular}

\subsection{Case 4: Manipulation of Discharge Pressure of LP Compressor (K-2430)}

The flowrate of LP gas compressor, gas flared rate, total power of compressors and suction pressure at first stage of the compressor are shown in Table 9 and Table 10. The LP separator pressure inlet, $\mathrm{P}_{\mathrm{i}}$ is set up to 5 barg and 6 barg. This case is improvised from Case 1 by increasing the suction pressure and decreasing the discharge pressure at second stage of the compressor from 23 barg to 22 barg.

Table 9: Results of Case 4 for 5 barg feed pressure.

\begin{tabular}{cccc}
\hline $\begin{array}{c}\text { LP gas compressor } \\
\text { flowrate (mmscfd) }\end{array}$ & $\begin{array}{c}\text { Flared gas flowrate } \\
(\text { mmscfd })\end{array}$ & $\begin{array}{c}\text { Total power of } \\
\text { compressor }(\mathrm{kW})\end{array}$ & $\begin{array}{c}\text { Suction pressure at 1st } \\
\text { stage compressor (barg) }\end{array}$ \\
\hline 21 & 10.0 & 2025 & 3.772 \\
22 & 9.0 & 2088 & 3.887 \\
23 & 8.0 & 2150 & 4.024 \\
24 & 7.0 & 2208 & 4.127 \\
25 & 6.0 & 2262 & 4.257 \\
26 & 5.0 & 2323 & 4.392 \\
27 & 4.0 & 2381 & 4.528 \\
28 & 3.0 & 2435 & 4.665 \\
29 & 2.0 & 2488 & 4.805 \\
30 & 1.0 & 2542 & 4.950 \\
31 & 0.0 & 2597 & 5.096 \\
\hline
\end{tabular}


Table 10: Results of Case 4 for 6 barg feed pressure.

\begin{tabular}{cccc}
\hline $\begin{array}{c}\text { LP gas compressor } \\
\text { flowrate (mmscfd) }\end{array}$ & $\begin{array}{c}\text { Flared gas flowrate } \\
(\mathrm{mmscfd})\end{array}$ & $\begin{array}{c}\text { Total power of } \\
\text { compressor }(\mathrm{kW})\end{array}$ & $\begin{array}{c}\text { Suction pressure at 1st } \\
\text { stage compressor (barg) }\end{array}$ \\
\hline 21 & 10.0 & 2021 & 3.816 \\
22 & 9.0 & 2084 & 3.931 \\
23 & 8.0 & 2146 & 4.048 \\
24 & 7.0 & 2204 & 4.169 \\
25 & 6.0 & 2260 & 4.300 \\
26 & 5.0 & 2321 & 4.436 \\
27 & 4.0 & 2378 & 4.571 \\
28 & 3.0 & 2433 & 4.708 \\
29 & 2.0 & 2486 & 4.848 \\
30 & 1.0 & 2537 & 4.990 \\
31 & 0.0 & 2591 & 5.133 \\
\hline
\end{tabular}

The flared gas flowrate as a function of LP gas compressor flowrate is plotted in Figure 11. The results indicate that the flared gas is affected by the flowrate of LP gas compressor in which the flared flowrate is reduced while gas feed flows to the LP compressor is increased. Both separator inlet pressures allow maximum gas flowrate of $25 \mathrm{mmscfd}$ to be directed to the LP compressor while the remaining $6 \mathrm{mmscfd}$ gas is diverted to the flare due to the total power requirement $(\leq 2280 \mathrm{~kW})$.

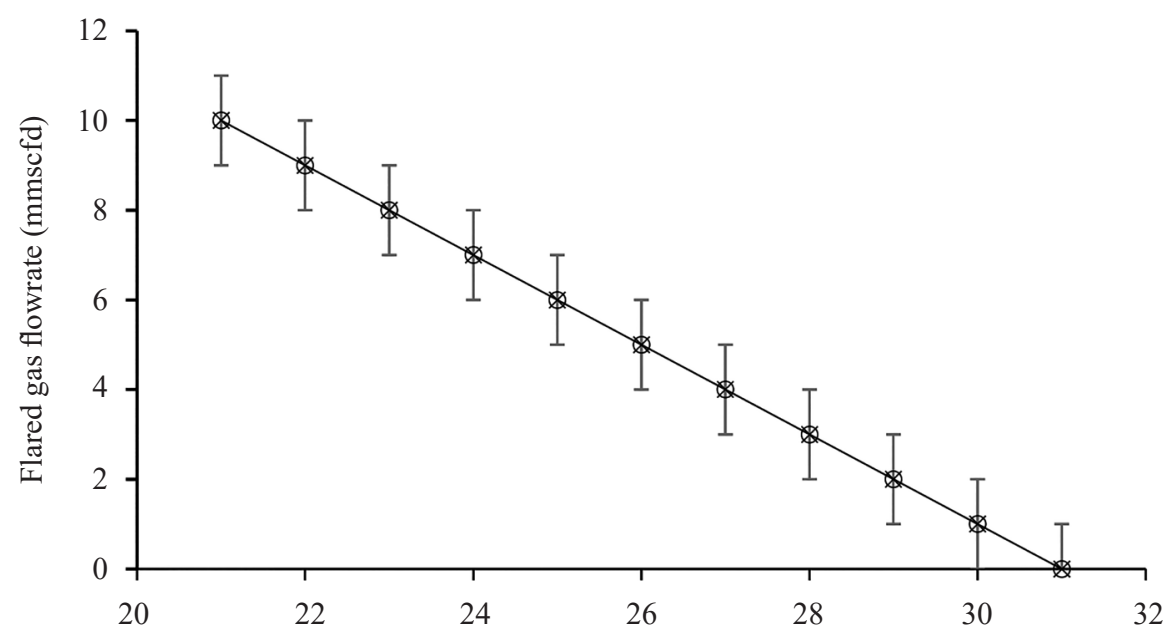

Flowrate of LP gas compressor (mmscfd)

Figure 11: Flared gas flowrate against flowrate of LP gas compressor (Case 4). 
Figure 12 shows that the total power of compressor is $2262 \mathrm{~kW}$ for separator inlet pressure of 5 barg and $2260 \mathrm{~kW}$ for separator inlet pressure of 6 barg. Similar to Case 1 and Case 3, the total power of compressor is limited to $2280 \mathrm{~kW}$.

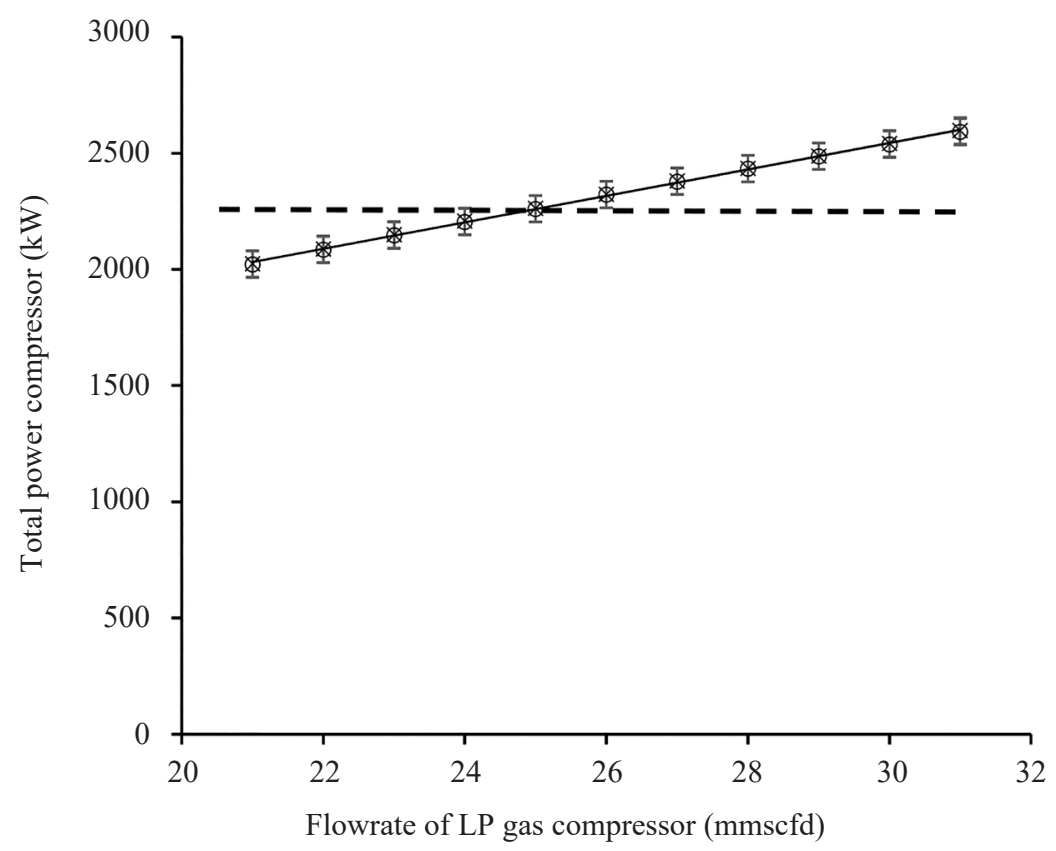

Figure 12: Total power against flowrate of LP gas compressor (Case 4).

Figure 13 shows relationship between the suction pressures at first stage of compressor versus flowrate of LP gas compressor. The suction pressure increases with increasing flowrate of the LP compressor. The calculated suction pressure is 4.30 barg.

The final case where the discharge pressure of LP compressor is decreased to 22 barg and the calculation for the discharge pressure loss has to be made. ${ }^{31}$ The velocity of the gas to flow through the pipeline is $3.74 \mathrm{~m} \mathrm{~s}^{-1}$ which is lower compared to the other three cases. The corresponding pressure loss is 2.966 bar. Knowing that the receiving end at Samarang Platform requires a minimum of 18 barg arrival pressure, lowering the discharge pressure to 22 barg appears feasible and practicable since the total discharge pressure loss is merely $3 \mathrm{barg}$. From the result of valve sizing calculation shown in Table 11, the opening valve for both feed pressure is considered good. 


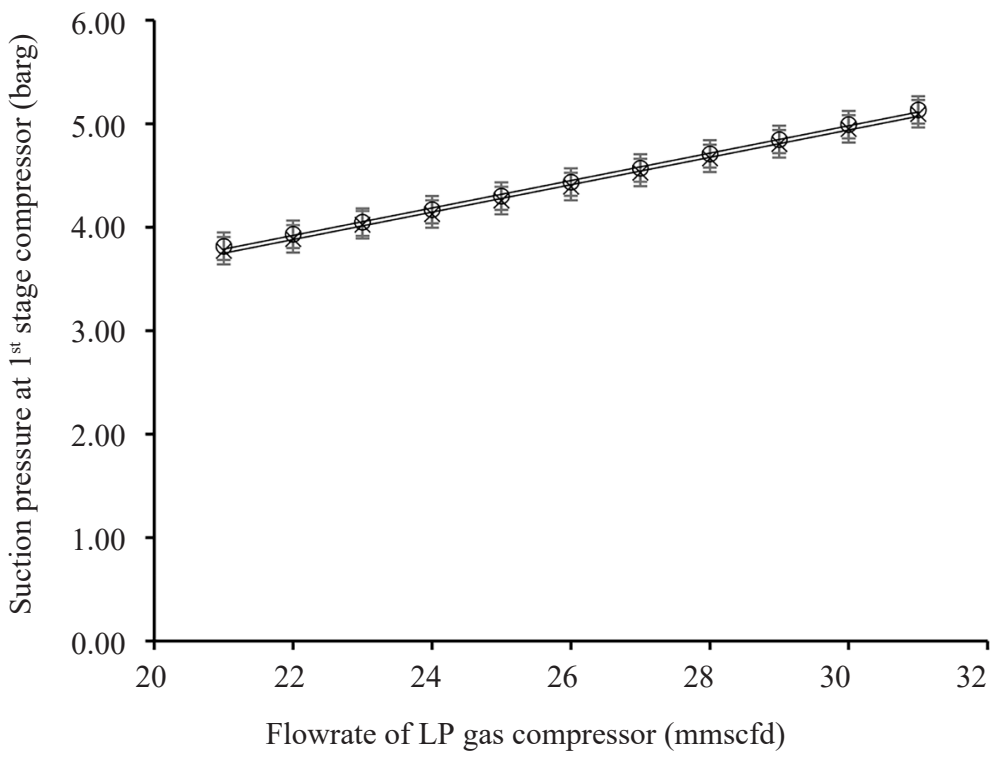

Figure 13: Suction pressure at first stage of compressor against flowrate of LP gas compressor (Case 4).

Table 11: Characteristics of PCV-1030A (Case 4).

\begin{tabular}{lcc}
\hline Characteristics & $\begin{array}{c}\text { Feed pressure } \\
(5 \text { barg })\end{array}$ & $\begin{array}{c}\text { Feed pressure } \\
(6 \text { barg })\end{array}$ \\
\hline Pressure drop (bar) & 0.7 & 1.7 \\
Mass Flowrate $\left(\mathrm{kg} \mathrm{h}^{-1}\right)$ & 27,090 & 40,305 \\
Fluid (liquid and vapour) density $\left(\mathrm{kg} \mathrm{m}^{-3}\right)$ & 4.7 & 5.4 \\
Calculated valve sizing coefficient, $\mathrm{Cv}$ & 855.58 & 559.80 \\
Flow characteristic - Opening (\%) & 82.3 & 53.8 \\
Opening valve operating characteristic - Linear (\%) & 82 & 54 \\
\hline
\end{tabular}

\section{CONCLUSION}

There is a concern on sustainable gas production and pollution issue in the oil platform due to the gas flaring. Here, we learned that the flared gas flowrate generally decreases as the flowrate of LP gas compressor increases. The excess gas that is routed to the flare system can be reduced when the capacity of the compressor is bigger and able to take up the maximum $31 \mathrm{mmscfd}$ feed gas flowrate. This shall fulfil the company's goal to achieve zero flaring when the gas flowrate of up to $31 \mathrm{mmscfd}$ is fed into the LP gas system. Even though the 
other cases do not achieve zero flaring, Case 3 can still reduce the flared gas to $1 \mathrm{mmscfd}$. Case 1 and Case 4 attain the minimum flared gas flowrate of $7 \mathrm{mmscfd}$ and $6 \mathrm{mmscfd}$, respectively. Case 2 (a new higher capacity compressor at feed pressure of $6 \mathrm{barg}$ ) and Case 3 (modifying the existing compressor) are the two best options to reduce the flared gas. Case 2 gives absolute possibility of zero flared rate but a new compressor is needed since the power of the compressor is large enough to take up the pressure. However, there will be cost implication of the new compressor installation and its associated operating expenditure. The cost implication will not be covered in the paper since it is beyond the scope of our study. It shall be dealt with appropriately in another paper. Meanwhile, Case 3 reduces flare gas to $1 \mathrm{mmscfd}$ but the compressor has to be modified using a new performance curve to maintain the power requirement below $2280 \mathrm{~kW}$.

\section{ACKNOWLEDGEMENTS}

The authors gratefully acknowledge the support from the Universiti Sains Malaysia through the Bridging (304.PJKIMIA.6316102) and Research University (1001. PJKIMIA.8014115) grants. The authors also acknowledge the support from the Fundamental Research Grant Scheme (FRGS) for Geran Sanjungan Penyelidikan (GSP), Ministry of Higher Education (MOHE) Malaysia, to enable the production of this article in collaboration with Repsol Malaysia (Talisman Malaysia Limited), JED Centre and Ibiden Electronics Malaysia.

\section{REFERENCES}

1. Furuoka, F. (2016). Natural gas consumption and economic development in China and Japan: An empirical examination of the Asian context. Renew. Sust. Energ. Rev., 56, 100-115, https://doi.org/10.1016/j.rser.2015.11.038.

2. Nwakire, C. (2014). The impact of gas flaring on the air quality: A case study of Izombe in Earstern Nigeria. Int. J. Eng. Res. Rev., 2, 61-71.

3. Elvidge, C. D. et al. (2009). A fifteen year record of global natural gas flaring derived from satellite data. Energy, 2, 595-622.

4. US Energy Information Administration, EIA. (2014). International energy outlook 2014. Retrieved 7 February 2016 from http://www.eia.doe.gov/oiaf/ieo/ pdf/0484(2004).pdf.

5. Johnson, M. R. \& Coderre, M. R. (2012). Opportunities for $\mathrm{CO}_{2}$ equivalent emissions reductions via flare and vent mitigation: A case study for Alberta, Canada. Int. J. Greenh. Gas Con., 8, 121-131, https://doi.org/10.1016/j.ijggc.2012.02.004.

6. Othman, M. R. et al. (2009). Strategic planning on carbon capture from coal fired plants in Malaysia and Indonesia: A review. Energy Policy, 37, 1718-1735, https://doi.org/10.1016/j.enpol.2008.12.034. 
7. Helwani, Z. et al. (2016). In-situ mineralization of carbon dioxide in a coal-fired power plant. Energy Sour. A, 38, 606-611, https://doi.org/10.1080/15567036.201 3.813991 .

8. Wiheeb, A. D. et al. (2013). Present technologies for hydrogen sulfide removal from gaseous mixtures. Rev. Chem. Eng., 29(6), 449-470, https://doi.org/10.1515/ revce-2013-0017.

9. Rahimpour, M. R. et al. (2012). A comparative study of three different methods for flare gas recovery of Asalooye gas refinery. J. Nat. Gas Sci. Eng., 4, 17-28, https://doi.org/10.1016/j.jngse.2011.10.001.

10. Wiheeb, A. D. et al. (2016). Pressure swing adsorption technologies for carbon dioxide capture: A review. Sep. Purif. Rev., 45, 108-121, https://oi.org/10.1080/ 15422119.2015.1047958.

11. Martunus et al. (2012). In-situ carbon dioxide capture and fixation from a hot flue gas. Int. J. Greenh. Gas Con., 6, 179-188, https://doi.org/10.1016/j.ijggc.2011.11.012.

12. Bae, S. et al. (2018). Rapid solvothermal synthesis of microporous UiO-66 particles for carbon dioxide capture. Kor. J. Chem. Eng., 35(3), 764-769, https://doi.org/10.1007/s11814-017-0334-4.

13. Rosli, A. et al. (2017). Advances in liquid absorbents for $\mathrm{CO}_{2}$ capture: A review. J. Phy. Sci., 28(1), 121-144, https://doi.org/10.21315/jps2017.28.s1.8.

14. Abdul Wahab, M. S. et al. (2017). Biomethane purification using PVDF/Pebax 1657 thin film composite membrane. J. Phy. Sci., 28(1), 39-51, https://doi.org/ 10.21315/jps2017.28.s1.3.

15. Wiheeb, A. D., Kim, J. \& Othman, M. R. (2015). Highly perm-selective microporous hydrotalcite-silica membrane for improved carbon dioxide-methane separation. Sep. Sci. Technol., 50, 1701-1708, https://doi.org/10.1080/01496395. 2014.987300.

16. Othman, M. R. (2009). Permeability and separability of methane and carbon dioxide across meso-porous $\mathrm{Mg}$-Al hydrotalcite and activated carbon media. Chem. Eng. Sci., 64, 925-929, https://doi.org/10.1016/j.ces.2008.10.056.

17. Othman, M. R., Tan, S. C. \& Bhatia, S. (2009). Separability of carbon dioxide from methane using MFI zeolite-silica film deposited on gamma-alumina support. Microp. Mesop. Mater., 121, 138-144, https://doi.org/10.1016/j.micromeso. 2009.01.019.

18. Wiheeb, A. D. et al. (2017). Flow dynamics of gases inside hydrotalcite-silica micropores. Micro. Mesop. Mater., 246, 37-42, https://doi.org/10.1016/j. micromeso.2017.03.021.

19. Seman, S. Z. A. et al. (2019). Optimizing purity and recovery of biogas methane enrichment process in a closed landfill. Renew. Energy, 131, 1117-1127, https://doi.org/10.1016/j.renene.2018.08.057.

20. Myint, P. C. et al. (2016). Application of the Peng-Robinson equation of state to energetic materials RDX and TNT: Pure components, liquid mixtures, and solid mixtures. Ind. Eng. Chem. Res., 55, 2252-2266, https://doi.org/10.1021/ acs.iecr.5b04808. 
21. Li, C., Jia, W. \& Wu, X. (2012). Application of Lee-Kesler equation of state to calculating compressibility factors of high pressure condensate gas. Energy Proced., 14, 115-120, https://doi.org/10.1016/j.egypro.2011.12.904.

22. Talisman Malaysia Limited. (2013). Kinabalu (KNDP-A) debottlenecking studies, s.1. Kuala Lumpur: Talisman Energy.

23. Sarawak Shell Berhad. (2009). Kinabalu operating manual, s.l. Kuching: Sarawak Shell Berhad.

24. Male, J. V. (1978). A newly developed refrigerating compressor. Int. J. Refrig., 1, 242-248, https://doi.org/10.1016/0140-7007(78)90121-4.

25. Baghmolaei, M. M. et al. (2014). Operation analysis of rotary tools of compressor station using exergy approach. Int. J. Eng., 27, 1815-1822.

26. Barton, M. T. et al. (2014). Numerical optimization of a vaned shroud design for increased operability margin in modern centrifugal compressors. J. Turbomach., 128, 627-631, https://doi.org/10.1115/1.2187526.

27. Fisher. (1999). Control valve handbook, 3rd ed. Iowa: Fisher Control International.

28. Azin, R. et al. (2014). Integrated analysis of choke performance and flow behaviour in high-rate, deviated gas-condensate wells. Gas Proc. J., 2, 8-18.

29. Brown, R. N. (1997). Compressors selection and sizing, 2nd ed. Texas: Gulf Professional Publishing.

30. Hegberg, M. C. (2000). Control valve selection for hydronic system. ASHRAE J., 42, 33-39.

31. Kotp, N. A., Elashmawi, W. H. \& Tawel, G. E. (2016). Performance deterioration of gas turbine: Survey and challenges ahead. Int. J. Eng. Res., 4, 285-299. 